\title{
Rediscovering the 19th Century of a Port Town in Levant: Smyrna/Izmir
}

\author{
By Burcu Taşci* \\ Büke Özden ${ }^{\dagger}$ \\ Fatma Davras \\ Hümeyra Birol Akkurt ${ }^{+}$
}

Till 16th century, the city of Izmir that located around a sheltered bay surrounded by rivers, valleys and mountains was a small town with an economy based on farming activities. In the 17th century, in accordance with the large trade volume of the Mediterranean era, the city had become an important port not only in Ottoman lands but also in the east Mediterranean. As a result of its importance for the region and for the commerce network, the city attracted attention of travellers from the 16th century with an increasing frequency in the 17th century. The travellers who visited the city had shared their experiences related to the geography, topography, economy and socio-cultural life of Izmir through their notes, paintings and the photographs. In this context, this paper aims to rediscover the city of Izmir through the experiences of the travellers. As the data related to the 19th century of the city is much more varied such as travel notes, engravings, maps and photographs, the study focuses on the 19th century. With the aim of rediscovering the culture-space relations of the city through the observations and expressions of the travellers, the physical and socio-cultural formation of the city will be examined while the differential perceptions and comments will be evaluated through a comparative study.

\section{Introduction}

The city of Smyrna, has been one of the important coastal settlements of the Western Anatolia. Established about 8500 years ago, this harbour city has ruled by different civilizations such as Ionians, Romans, Byzantines, Seljuks but gained its importance under the rule of Ottoman Empire between $15^{\text {th }}$ and $19^{\text {th }}$ centuries.

In the $15^{\text {th }}$ century, the city of Izmir that located on the outskirts of Kadifekale expanded towards the coastline. Till $16^{\text {th }}$ century, the economy of

\footnotetext{
*Architect, Research Assistant, Izmir Katip Celebi University, Turkey.

${ }^{\dagger}$ Architect, Izmir, Turkey.

${ }^{\ddagger}$ Architect, Izmir, Turkey.

${ }^{+}$Architect, Associate Professor, Dokuz Eylul University, Turkey.
} 
the city was heavily depended on agriculture. Due to the expansion of the city and the developing harbour, Izmir became an important market and a trade centre in the second half of the $16^{\text {th }}$ century. In between 16th and 18th centuries, in accordance with the changes of the trade system in the Mediterranean era, the city developed as an important harbour city. As a result of the changes in the economical system, a cosmopolitan society consisted of the Muslim Turks, Jews, Armenians, Greeks and Levantines was developed. Due to the social, economic and urban growth, the city became the largest external trade port of Ottoman Empire in 19th century.

Due to the developing economy, trade and cultural structure consisted of the historic and natural environment besides the ethnic and religious diversity, the city attracted attention of a large number of western travellers from England, France and Germany, besides the limited number of travellers from the east. These travellers observed and described Izmir through its physical, social and cultural structures while some of them mentioned the geographical and topographic structure of the city .

The increasing economical and trade importance of the city, its geographical location and ethnic, cultural and religious diversity drew many travellers to the city between 17 and 20th century. Along with Turkish travellers, the city was also visited by western travellers from England, France and Germany, whereas few travellers from the east came to Izmir. Most of these travellers' work and observations focused on the physical, social, cultural, geographical and topographic structure of the city. In other words, the descriptions, narrations and drawings of the travellers figure out the story of Izmir through the eyes and perceptions of the story tellers. With the aim of understanding the history of the city through different sources, this study focuses on the descriptions of the travellers. With this aim, it is tried to rediscover the $19^{\text {th }}$ century Smyrna, as one of the most important port towns of the Mediterranean Era of the period, through the experiences of the travellers.

\section{An Overview to 19th Century Izmir}

In order to understand the city through the experiences of the travellers, intaglios, photographs, postal cards and narrations have taken into consideration. Through the data that taken from these sources, the physical and social structure of the city is recoded. The different ethnic and religious groups, their living districts are defined, while the socio-cultural spaces such as theatres, operas, casinos and coffee houses and their affects on the city and its inhabitants are underlined. 
Figure 1. Smyrna in $17^{\text {th }}$ Century (De Bruyn, 1698, in Maeso\&Lesvinge, 2013 )

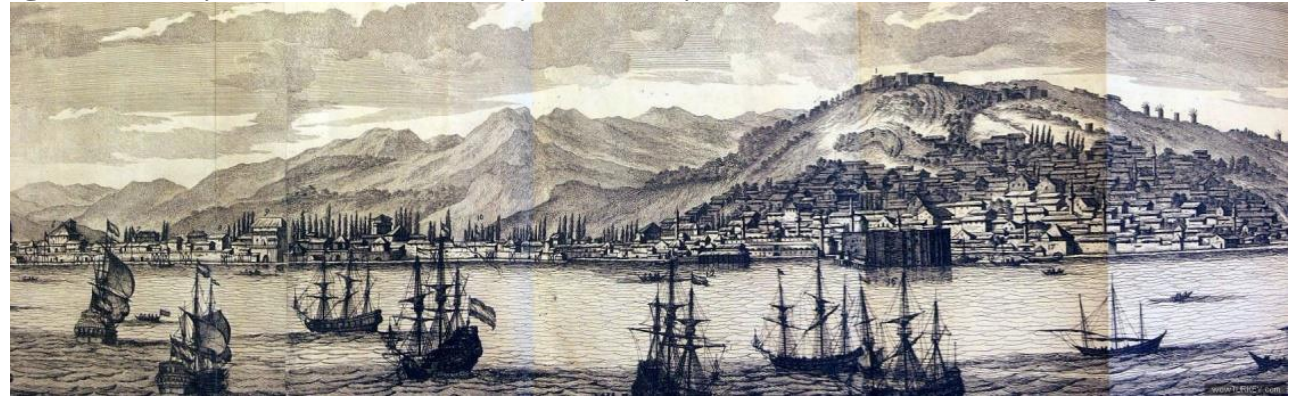

Figure 2. Smyrna in early $19^{\text {th }}$ Century (Turner, 1820, in Maeso\&Lesvinge, 2013)

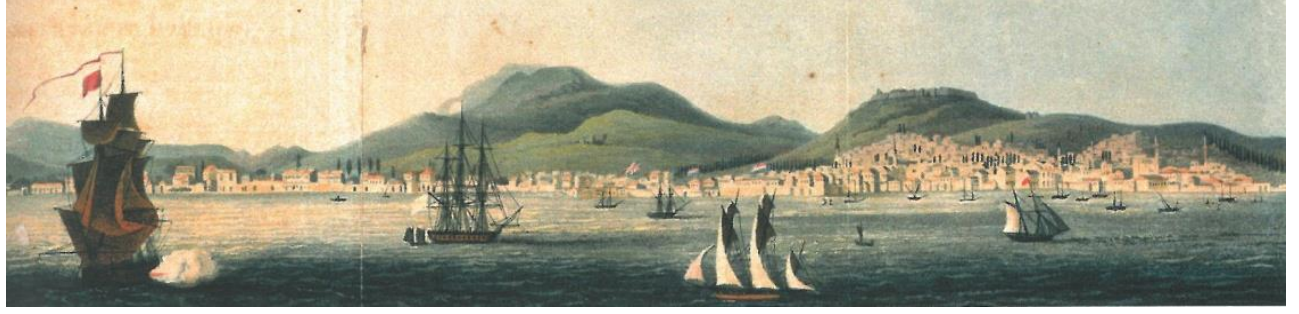

Figure 3. A Street in Smyrna in $19^{\text {th }}$ Ccentury (Allom, 1844, in Beyru, 2011)

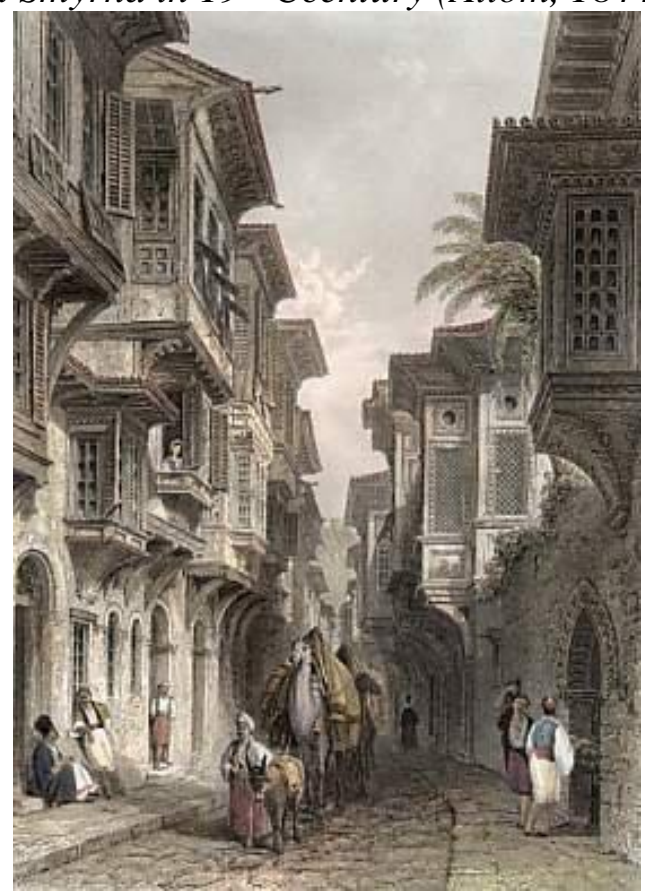

\section{Physical Structure}

As the Aegean Sea offered a safe transportation facility, the travellers arrived to the city from the harbour- the west, and the first sight was the beautiful panorama. They portrayed the city with its geographical features- the 
mountain of Pagos on the right; the harbour, the commercial ships and the military ones; and the urban tissue consisted of the religious buildings with their minarets/ bell towers and chaotic view of the housing districts.

In the narrations of Gauttier ve Döbel, Izmir described as an Eastern town and even the capital of Levant, whereas Lamartine, Haller and Nostitz compared Izmir with European cities such as Marseille, Naples and Trieste.

"...there arises the east with its long magnificent, great and colourful form" (Gauttier d'arc, 1829, in Yaranga, 2002)

"Izmir does not respond to my expectations from an east city, instead it is the Marseille of Asia minor" (Lamartine,1833, in Beyru, 2011)

"...Izmir can be remembered as a small port city along with the big port cities of the west such as Trieste and Marseille." (Haller, 1864, in Pinar, 1994)

Some of the travellers pointed out the Muslim character of the city. Prominent symbols of the city panorama inspired travellers in their narrations and reflections. Michaud described Smyrna as a Muslim city highlighting its minarets and graveyards.

"...The minarets and cypresses shadowing the graveyard signal that you are approaching to Muslim town.." (Michaud, 1830, in Yaranga, 2002)

On the contrary, some of the travellers drew attention to the lost beauties of the city. Nostitz stressed the various parts of the society, Döbel, pointed out the lost beauties of the Roman city. Some travellers, such as Döbel and Stackelberg, underlined that the city lost its beauty after been conquered by the Turks.

"...There are three rows of aqueduct which is quite contradictory with the spirit of Turkish city. What else could be expected from a town where a Roman civilisation went under the rule of Ottoman Empire!" (Nostitz, 1835, in Pinar, 1994)

"... Nothing left from the glorious days of Izmir. The city is no different than any other Turkish city...." (Döbel, 1832, in Pınar, 1994)

"Izmir was one of the most beautiful cities of Roman Empire. However, now the castle is demolished, there is no slave market and the architectural beauty of the mosques disappeared."'(Stackelberg, 1811, in Pinar, 1996)

The narrations of the travellers who concurrently visited the city show conflicts and differentiated perceptions. One of the reasons of these differentiations is the dual structure of the city. Due to the different life styles 
of the social groups; the housing districts of Turks, Jews and Armenians that located on the outskirts of the castle and the coastal parts inhabited by the Greeks and the Westerns, the urban and architectural forms showed diverse characters. Therefore, the travellers spending time in the neighbourhoods of Greeks and Westerns had a perception of a Western city, while the ones that spent their time in the Turkish neighbourhoods described the city as an Eastern character. The different portrayals can also be explained with the identities of the travellers, their professions, the purpose and the duration of their visit, the places they experienced and the people they met.

Figure 4. A Panorama of the City (Havil, 1818, in Maeso\&Lesvinge, 2013)

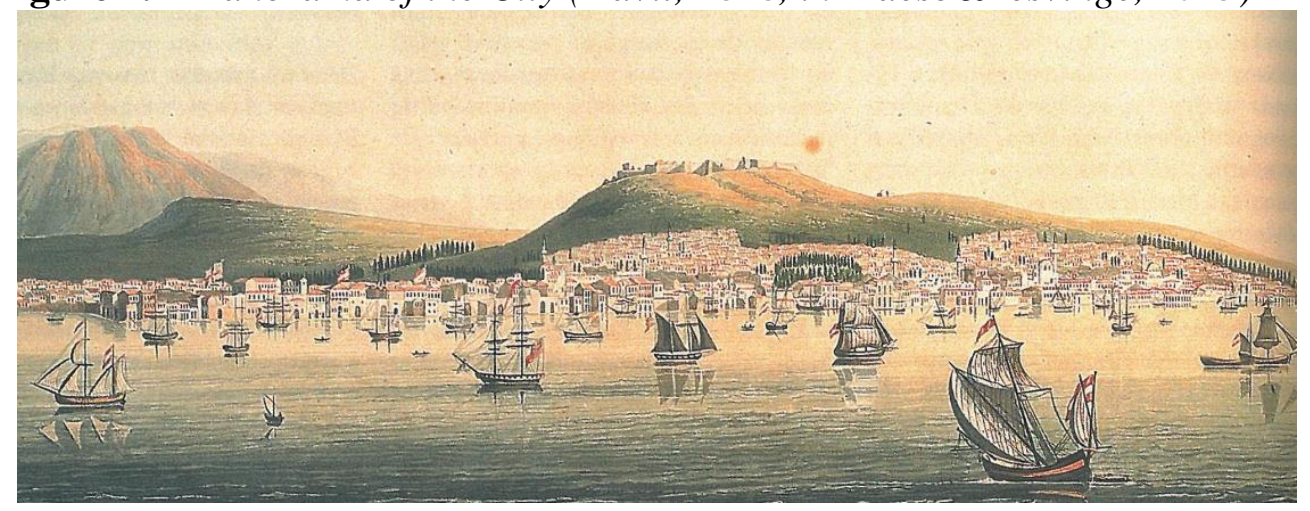

Figure 5. A Panorama of Turkish Neighbourhood (De Laborde, 1838, in Beyru,2011)

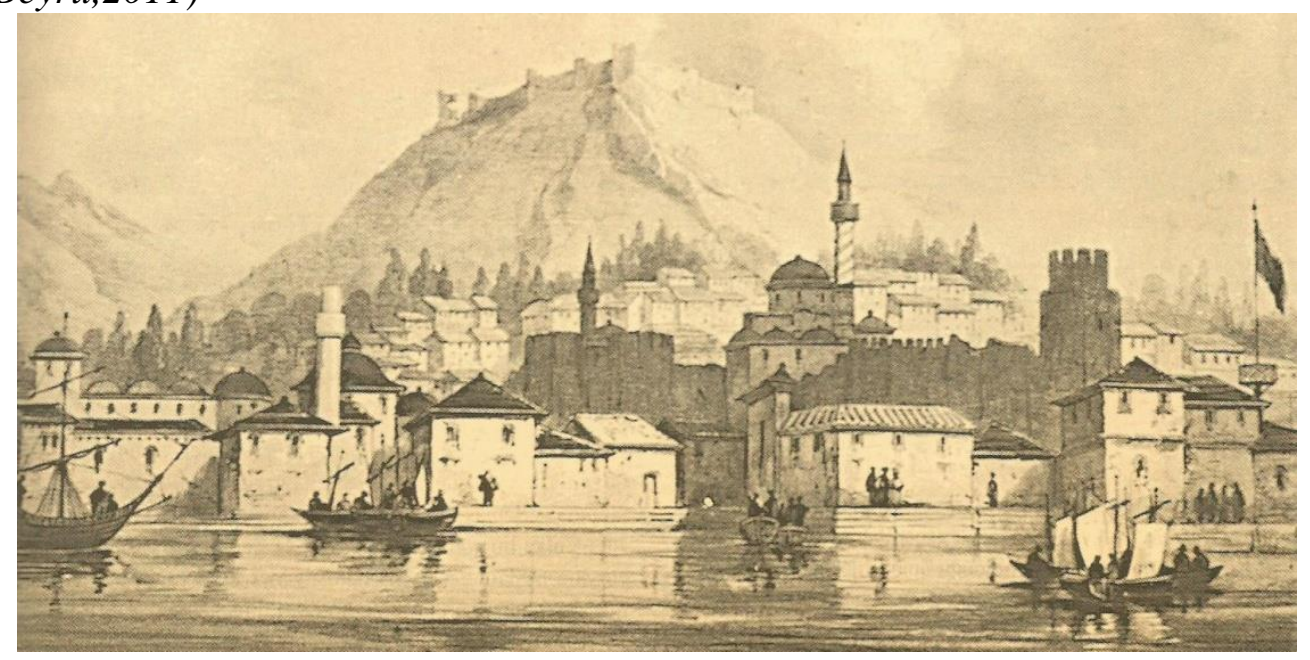

\section{Socio-Cultural Life}

The social structure of Izmir, in common with the other Ottoman cities, was multi-cultural and cosmopolitan. However, the living districts of the different religious and ethnic groups were separated in the urban structure. They preferred to form their own neighbourhood and live with their own community. These neighbourhoods differ distinctly from each other in terms of 
Vol. 1, No. 1 Taşci et al.: Rediscovering the $19^{\text {th }}$ Century of a Port Town in Levant...

physical and socio-cultural characteristics. Busch narrates these differentiated characters as follows:

"Izmir has five neighbourhoods. Frank neighbourhood is built on a big road with many side streets and is very European. Just behind the Frank neighbourhood, there are Greek and Armenian neighbourhoods which have Southern Europe style of houses. Then, there are Turkish and Jewish neighbourhoods with red roof tiles, white and red painted minarets, and large and small gardens. Their streets are generally narrow and paved badly. Despite the lively atmosphere and life in the harbour, houses facing the mountains are tranquil." (Busch, 1859-1864, in Pinar, 1996)

Busch's narrations also show that there was a cultural interaction between different ethnic groups and this interaction is reflected to the people's way of dressing, lives and even to the streets names.

"It is almost impossible to come across a Turkish cultural element in Frank neighbourhood. A foreigner can feel himself in an Italian city there (...) The Greeks adopted Frank way of dressing and normalised this style. Street names are usually in French. After war, they are also started to be named in German and English. One could come across many photograph studios and pharmacy laboratories. Here the houses are decorated like in Europe. The people who go for a walk along the harbour are very elegant and can compete with the distinguished world in Paris." (Busch, 1859-1864, in Pınar, 1996)

Figure 6. Locations of Neighbourhoods in $19^{\text {th }}$ Century (in Beyru, 2011)

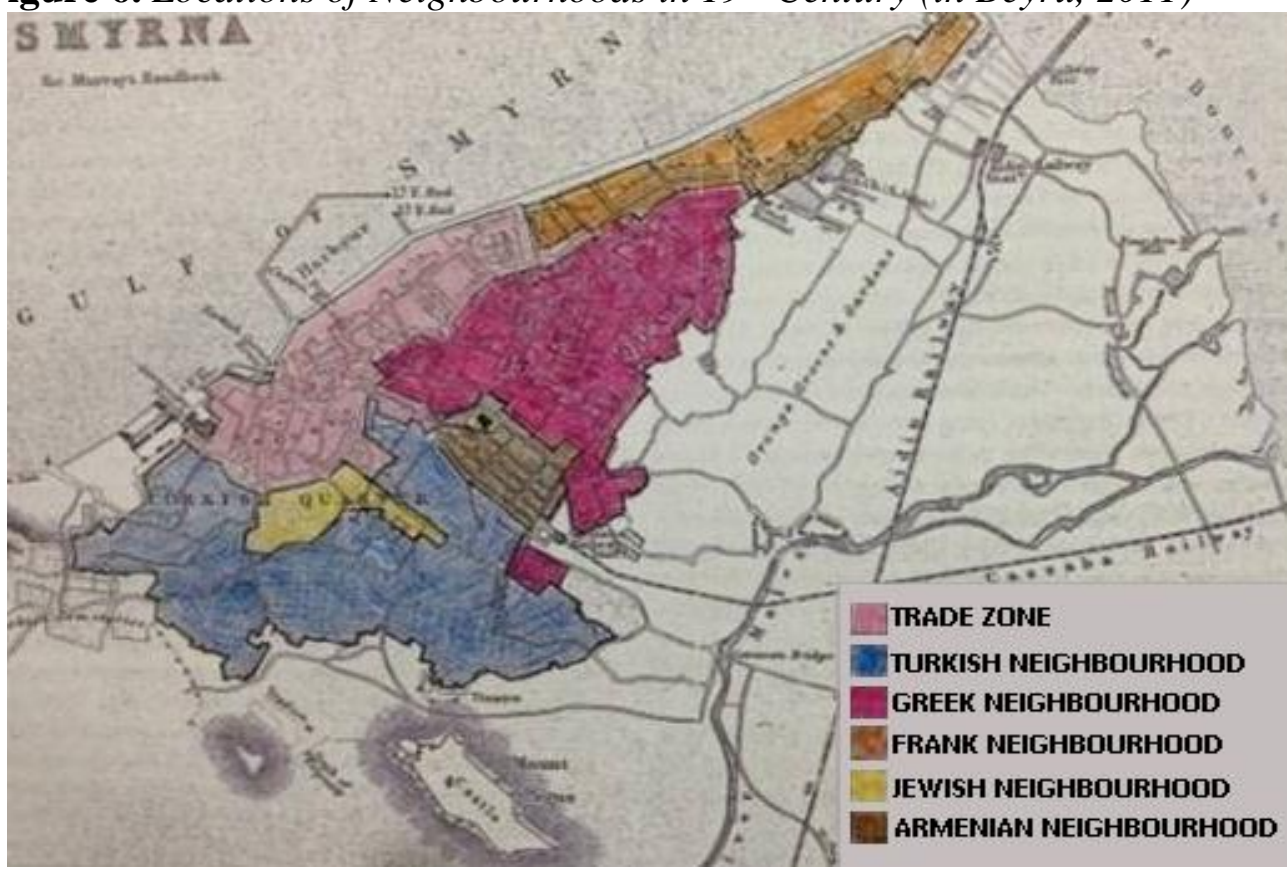




\section{Turkish Neighbourhood}

Most of the travellers described the Turkish neighbourhood as a chaotic and complicated structure with its labyrinth streets, lattice windows and the courtyards. Some of the travellers such as Nostitz and Kauder mentioned the issue of security within the Turkish district, while some others such as Lamartine had an adverse opinion about the Turks. He described them as honest, polite and hospitable people.

"Although Turkish people made up the majority of the city, I have not met any Turks during my visit. The Europeans living in this city would regard the narrow and dirty streets of the neighbourhood as dangerous." (Nostitz, 1835, in Pinar, 1994)

From the narrations, the street life and the production of the public space are also understood. As Lane stated, the streets of the Turkish neighbourhood were used by both the man and women.

"The Turks, except for tough winters, love to drink their coffees in outdoor under pergolas. They spend most of their time out than at their home. Women prefer to sit in front of their doorsteps in groups" (Lane, 1837, in Beyru, 2011)

Figure 7. A Panorama of Turkish Neighbourhood (Firth, the 1880s, in Beyru, 2011)

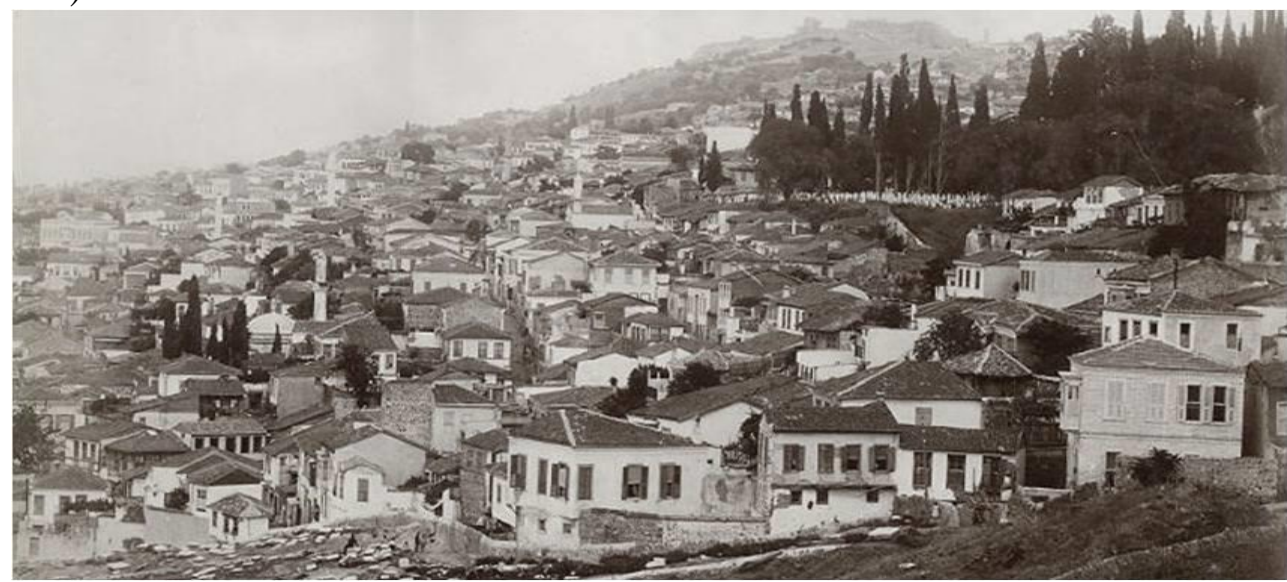

\section{Frank Neighbourhood}

As the Western travellers hosted by their own communities that lived in the Frank neighbourhood, this district was described in details. Besides, in a world of colonisation, the travellers had an important mission to explain and expand the western culture in the eastern lands. 
On the contrary, the frank neighbourhood was the core of the social life of the city in the 19th century besides its economic superiority over other neighbourhoods. The Consulates, the European market, posh aura of the neighbourhood with several art galleries and luxurious restaurants created a home-like atmosphere for these Western travellers. Therefore, it described as being cleaner, attractive and more elegant accordingly the other parts of the city.

"The most beautiful street of the city is the European populated Frank road. It is close to the port and has the most elegant houses, as well as all the Consulates " (Döbel,1832, in Pınar, 1994)

"Frank neighbourhood, which has the best paved streets and European houses, is the most prestigious area of Izmir."(Schubert, 1836, in Pinar, 1996)

Figure 8. View of the Port in $19^{\text {th }}$ Ccentury (Joaillier, 1890, levantineheritage. com)

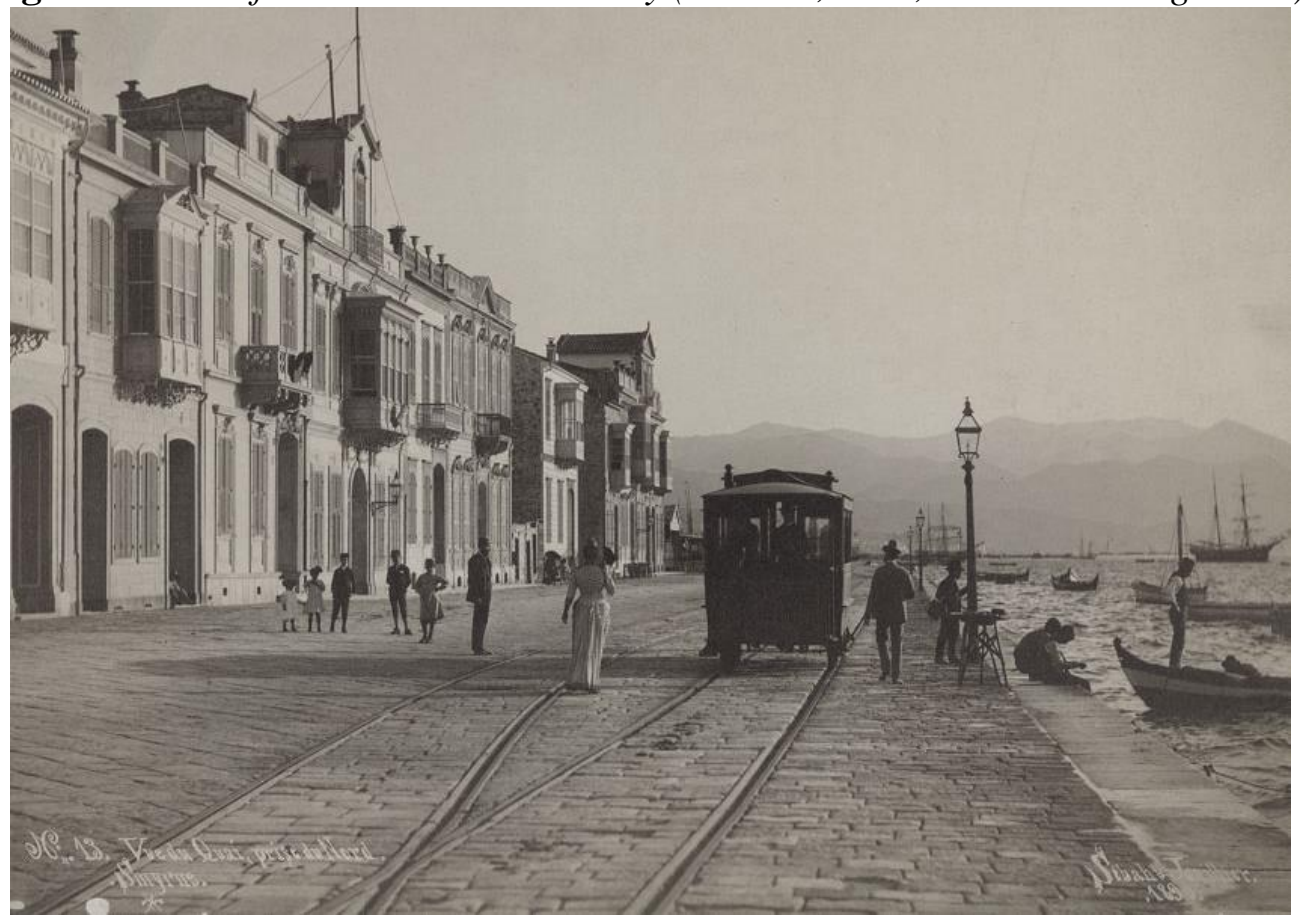

\section{Greek Neighbourhoods}

Travellers described the Greek neighbourhood as being caught up in clusters between Frank and Turkish neighbourhoods. Its streets are dirtier than Frank neighbourhood. Narrations suggest that the Greeks are social people who spend their lives in their gardens, yards or in front of their houses' doorsteps. Their interaction with the Franks influenced their way of dressing, social life and even architecture. The narrations pointed out the similar cultural and social elements with the Franks. 
Figure 9. View of the Greek Neighbourhoods (Cardpostal, in Beyru, 2011)

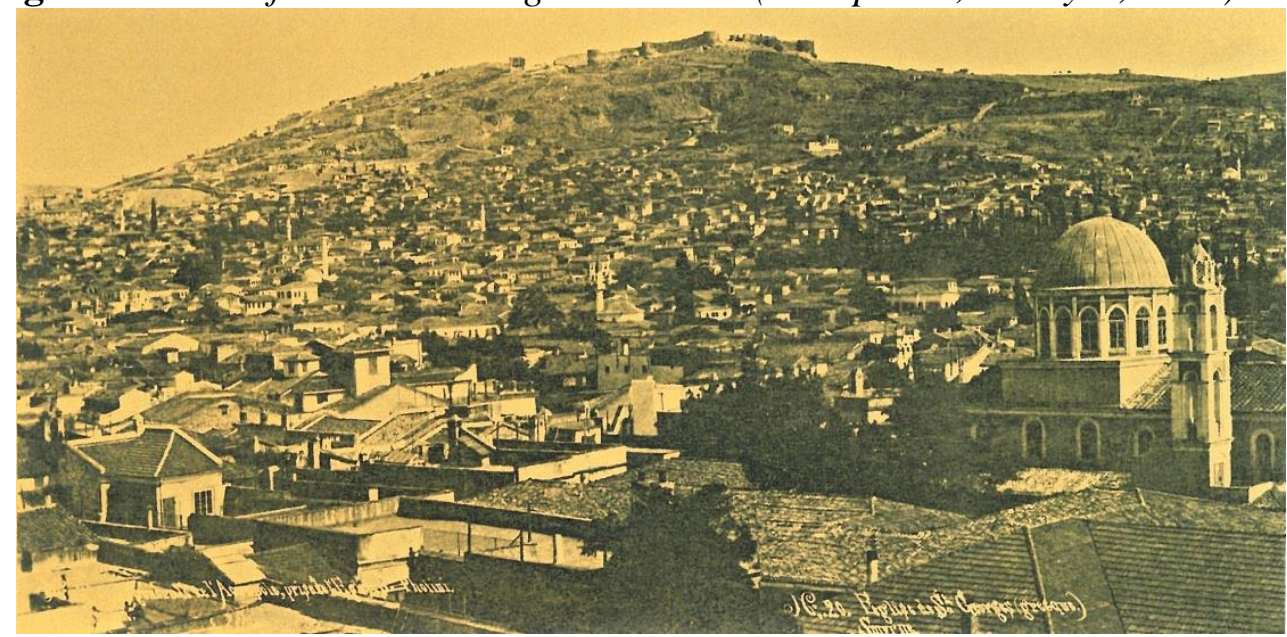

'The Greek neighbourhoods seem like Europe; however, you feel as if you are in the East. Lanes are dirtier than the Frank neighbourhood. Beyond the house doors opening up to the streets, there are patios, pools and gardens surrounded by orange and pomegranate trees. Towards evening, all doors are opened, sofas and chairs are carried out to the streets, and people visit each other and sit together. " (Busch, 1870, in Pinar, 1996)

\section{Jewish Neighbourhood}

In narrations of travellers, Jewish neighbourhoods appear as the most neglected district of Izmir. Its streets were described as dirty and its people as poor and sick. In this densely populated district, people were living in rented and multi dwelling units. Rolleston (1857) expressed his perceptions related to the district as follows:

"This district is the least pleasing neighbourhood (...) The striking characteristic of the neighbourhood are the density, poverty, the dirtiness of the streets, uncomfortable houses and ill-looking people." (Rolleston, 1857, in Beyru, 2011) 
Figure 10. Jewish Neighbourhoods (Müller, 1843, in Maeso\&Lesvinge, 2013)

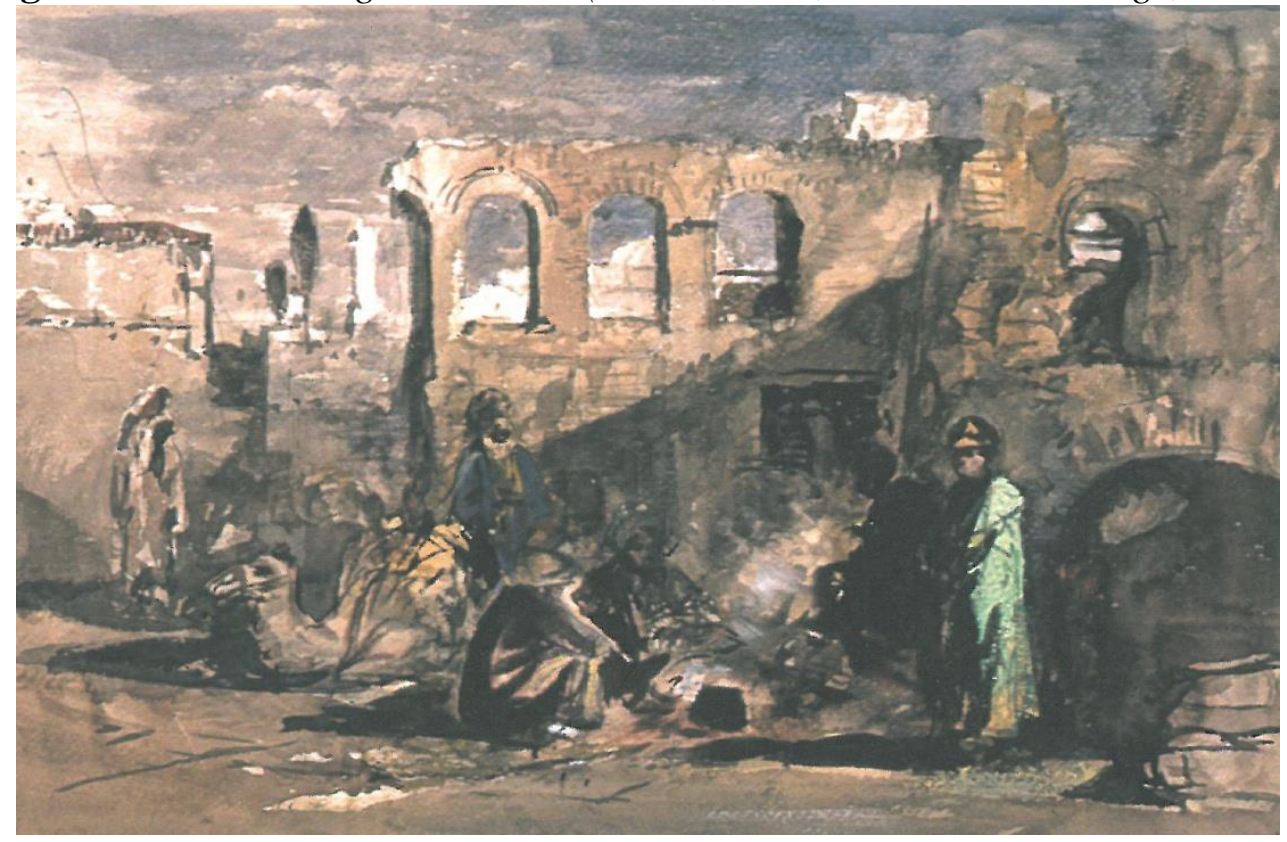

\section{Armenian Neighbourhood}

Unlike the Jewish district, the Armenian neighbourhood described as a qualified urban form with attractive houses and churches. The Armenians described as quite unsophisticated, earnest and clean people. Stephens (1835) pointed out how the Armenians highly valued and paid attention to their life spaces;

"The Armenian neighbourhood are superior to other neighbourhoods in terms of style and appearance. Its streets are wide, clean, and houses are neat and well-painted." (Stephens, 1835, in Beyru, 2011)

Despite the plain styles in their housing neighbourhood, the ornamentation in their churches stroked the attention of many travellers and stated as a contradiction with their plain life styles. The narrations underlined that the new Armenian Church rebuilt after 1845 fire is the biggest and the most spectacular structure of Izmir. The glory in their churches is presented as the reflection of the aura of their religious ceremonies which quietly different from other communities. 
Figure 11. Turkish, Greek and Armenian neighbourhoods (Cardpostal, Beyru, 2011)

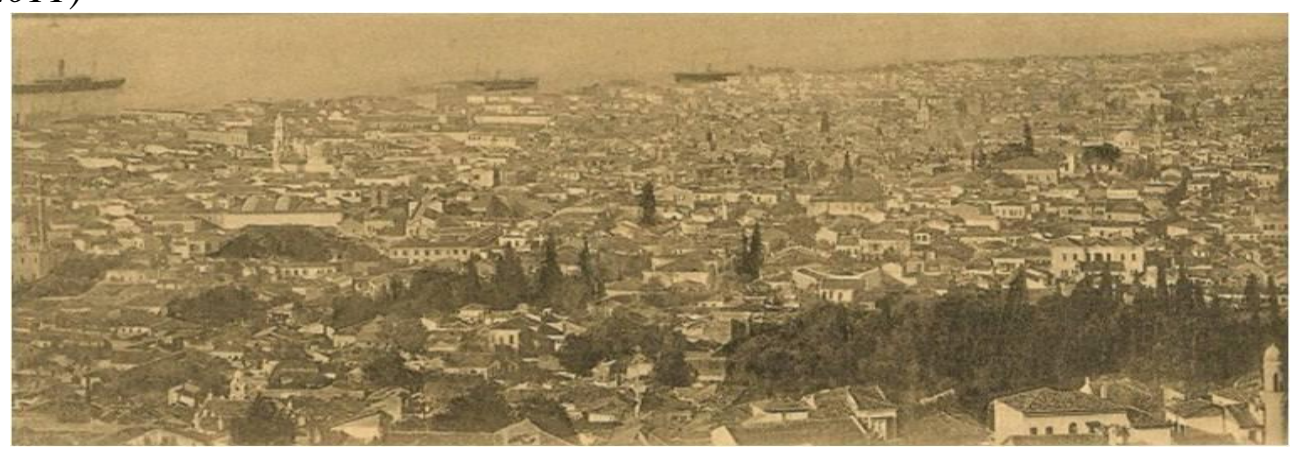

\section{Commercial Spaces}

Traditional commercial spaces are the most attractive, fascinating parts of the city of Smyrna. In most of the narrations, the traditional commercial spaces that were used and shaped by the Muslim communities were highlighted by their Eastern characters.

"The eastern markets have always been fascinating for me. The most striking things in the market was the public meal centre where dried food and desserts are generally sold. The Turks' favourite desserts are the milk based ones (...) What is interesting for a European is that there are no shops selling alcoholic drinks."(Fellows, 1838, in Pinar, 1994)

Figure 12. A Fish Market (Falmpu, 1837, in Beyru, 2011)

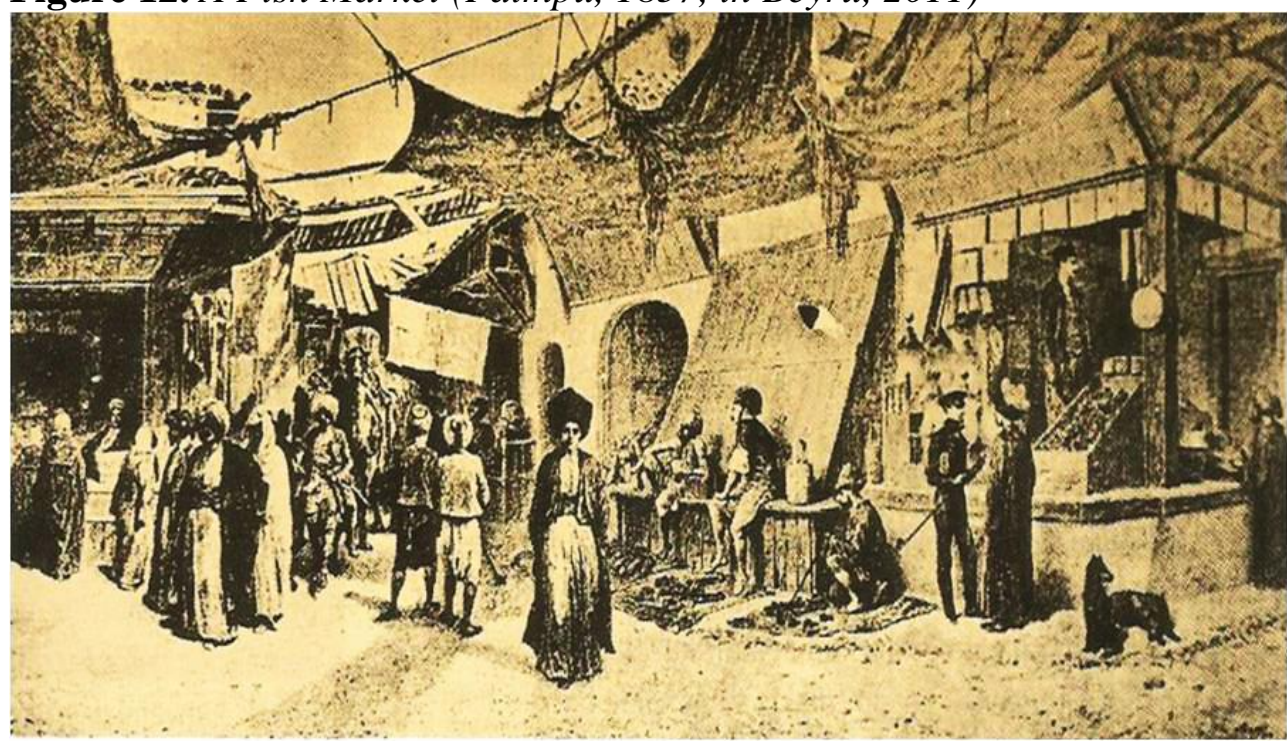


Vol. 1, No. 1 Taşci et al.: Rediscovering the $19^{\text {th }}$ Century of a Port Town in Levant...

Besides the urban and architectural forms of these spaces, the mostly mentioned issue is the camels that pass the lanes and narrow streets while carrying loads.

"When two camels came across in lanes, the one carrying less valuable load would sit down on its knees and the other one would jump over it. At this time, people on the streets would have to shelter in shops."(Schubert, 1836, in Pınar, 1996)

Figure 13. Caravane on Kervan Bridge (Allom, 19th century, in Beyru, 2011)

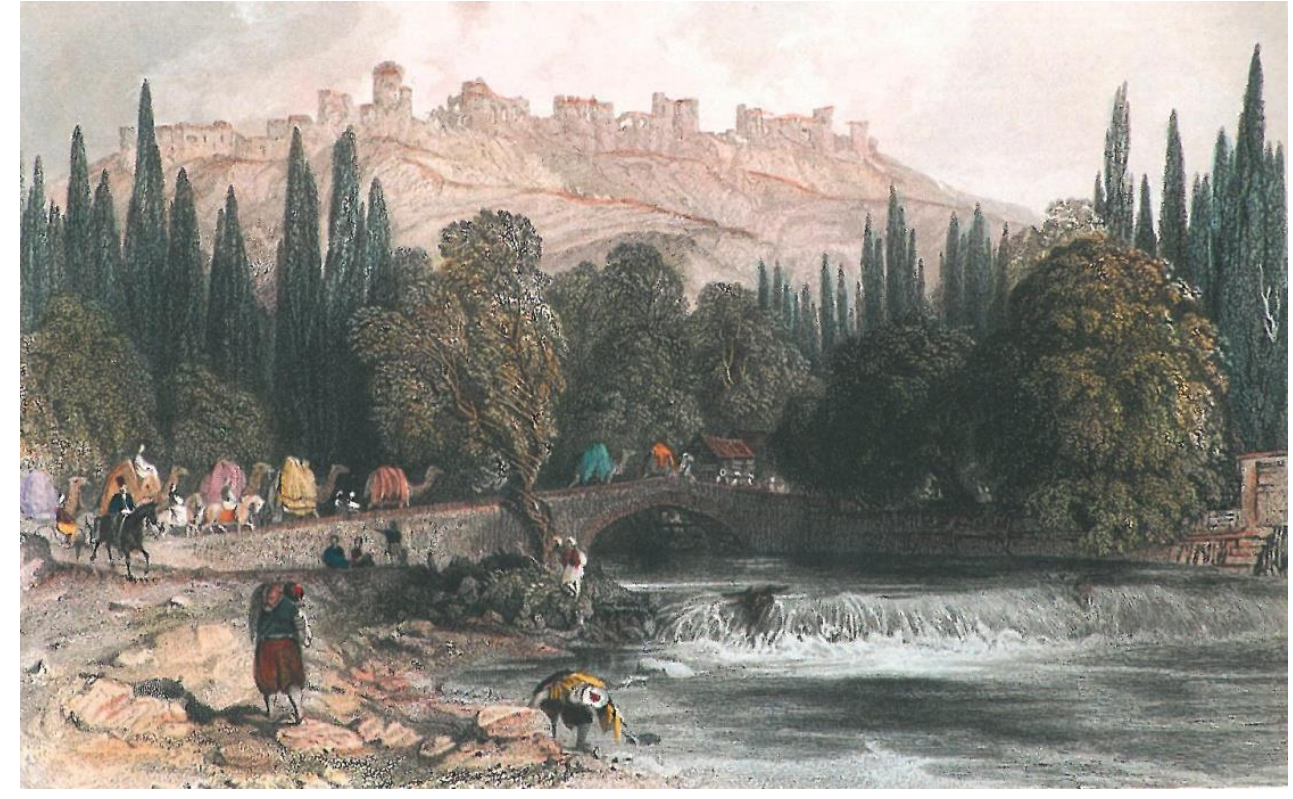

The other issue that have been told was the merchants. Many travellers mentioned the honesty of the Turkish merchants and the quality of their services. On the contrary, some others pointed out that there were also laidback and lazy merchants within the commercial life of Izmir.

"During my shopping in Izmir, I observed that The Turks marketed their goods in an honest way." (Colburn, 1829, in Beyru, 2011)

"If you see anyone squatting down quietly in front of their shop and smoking water pipe, he is most probably Turkish "(Laborde, 1838, in Beyru, 2011)

The Frank road, as the main commercial axe of the Western community with luxurious shops, bookshops, art galleries, photography shops and pharmacies, is one of the other most mentioned issue related to the commercial life of Izmir.

A number of travellers narrated that the best and newest buildings of the city took place on this road. They claimed the the road gave the feeling of taking a walk in a European city with its spectacular cobbles and narrow 
pavements. On the other hand, some other travellers described it as a market space for selling the imitations of European products.

'The Frank road is known to be the most beautiful road in Izmir. This narrow road seemed like a dirty stream with many houses in different colours on both sides of it and was badly pitched. It is possible to see shops on both sides of the road, linen and cotton laces hanged at head level and shadowing the road brightened by the sun, vegetable, melon or watermelon crumbles under your feet, stray dogs dragging their half eaten bones in mud and a crowd of people walking closely spaced and quietly with their soft shoes on." (Labitte, 1846, in Beyru, 2011)

Figure 14. Views from the Frank Road and the Fassoula Road (Rubellin, $1894 \& 1890$, levantineheritage.com)

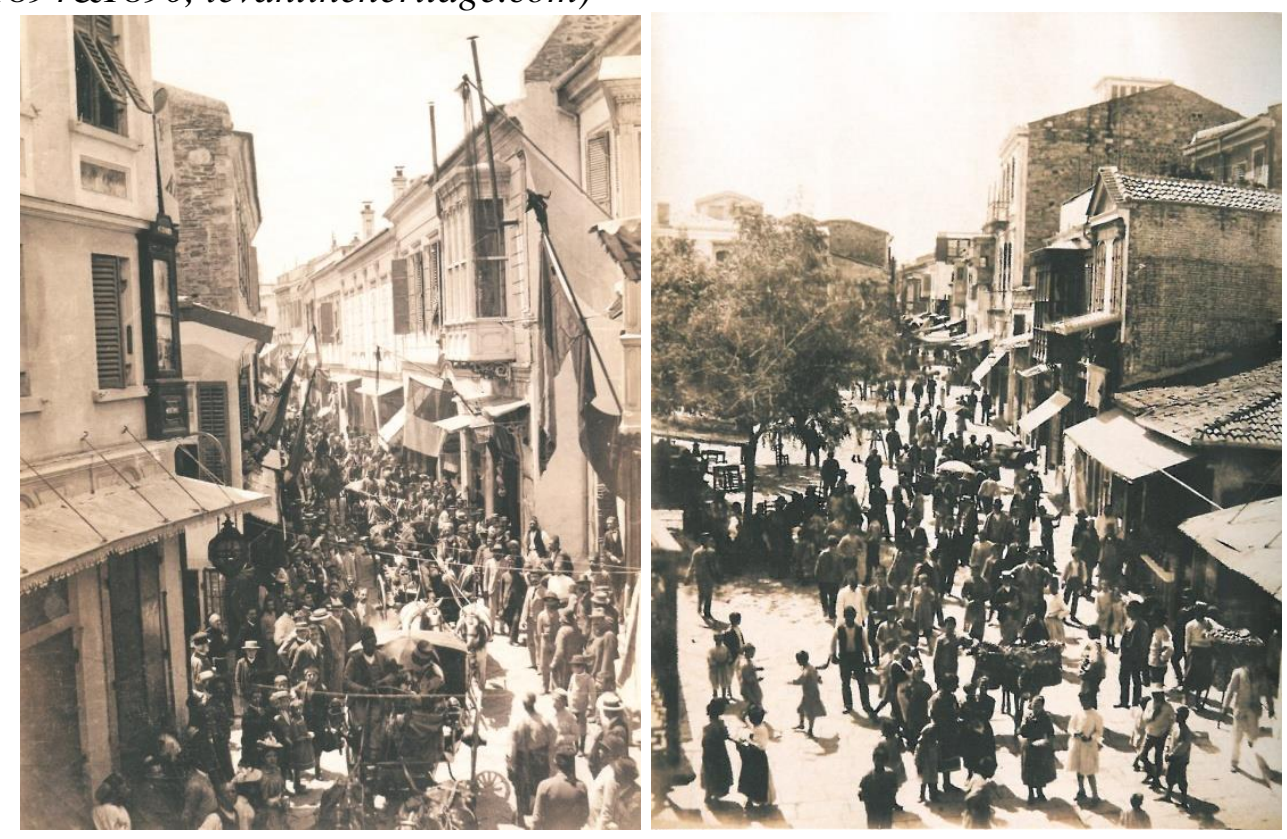

"The Frank road which represents the European life of Izmir starts from the north east of the town, continues through the marina and ends in the market place. 'Sultan Market' in the middle of the road makes up the most European part of the city with its finely pitched road connected to various passages. The market stuck among the houses can give false impression that it is a central shopping place where the traditional product of the city is being displayed. However, this market composed of interpenetrating buildings and roofed streets is also the centre of eastern industry. Both sides of the road is full of counters with colourful clothes. We leave the Frank road via a big gate and an incredible crowd meets us. Here you enter the east and leave the Europe behind, namely 'infidel Smyrna' (Barth, 1892, in Pinar, 1996) 
Vol. 1, No. 1 Taşci et al.: Rediscovering the $19^{\text {th }}$ Century of a Port Town in Levant...

\section{Cultural Spaces}

The dual structure of the city was also affected the cultural activities in the 19th century. The Muslims socialized by visiting neighbours, meeting up with them in their backyards or in front of their houses and having picnic at the weekends. On the other hand, the city offered various socialization opportunities to the non-Muslim citizens and the Western groups, such as theatres, clubs, coffeehouses, patisseries and pubs. These spaces that mostly located on the coastal line offer cultural interaction to the citizens of Izmir and brought their life philosophy, cultural values, consumption habits, sense of aesthetic and entertainment.

Figure 15. The Cultural Spaces located on Kordon- the coastline of the city. ( Set of Insurance Surveys from Smyrna, 1905, in Beyru, 2011)

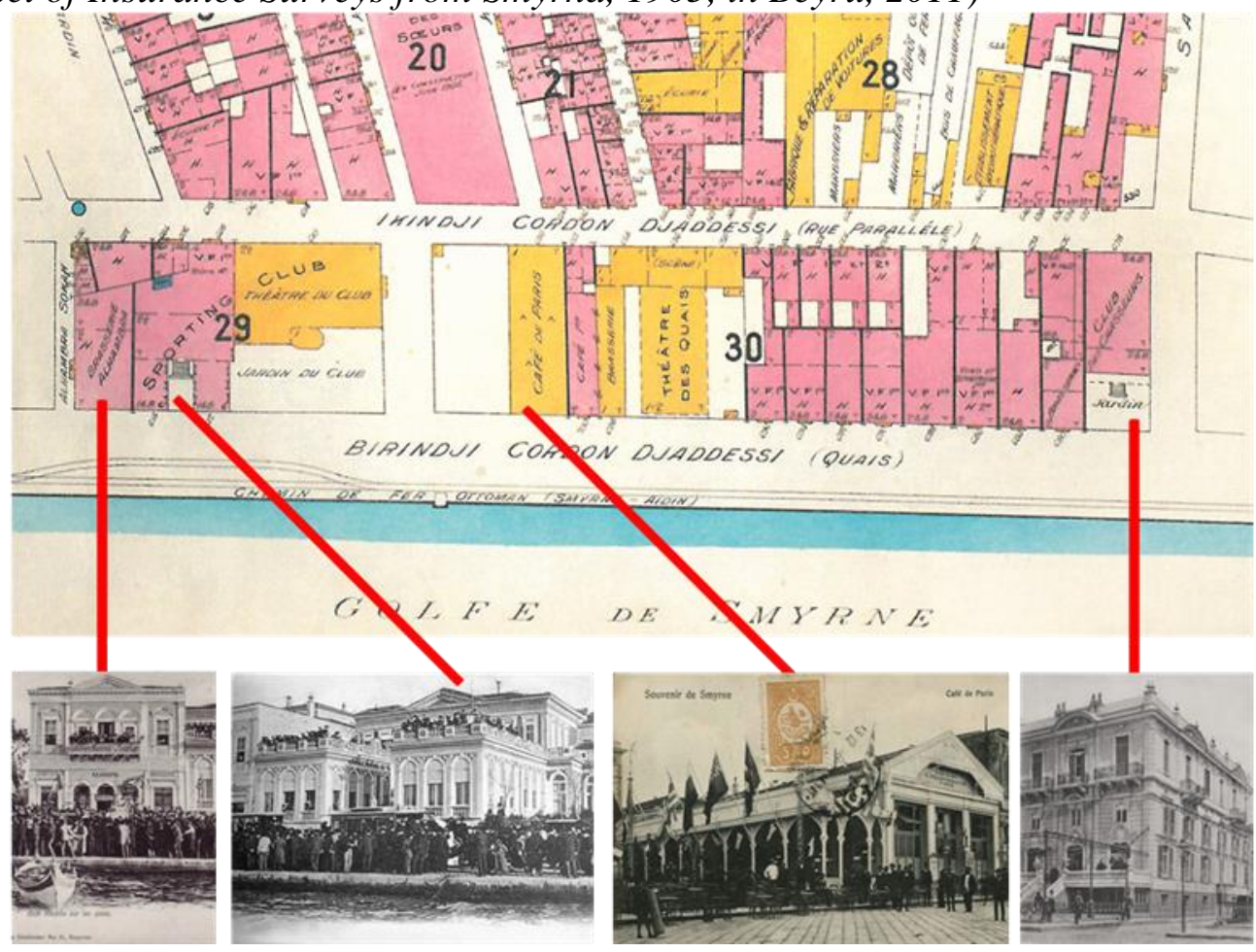

Travellers frequently mentioned the cultural activities of the Western groups and their spaces. Some of them figured out that the Western community continued their cultural life as it was in their homelands, while some others claimed that the cultural activities were insufficient and only a small group was interested in it. Theatres and operas approached quite critically within the narrations of Bush and Lindau;

"The theatre in the town is below the standard. A few Germans founded a singing clubs and they are not willing to open it to the public." (Busch,1859, in Pinar, 1996) 
"In a city like Izmir with half million population, there is not a proper theatre. This does not come as a surprise because Muslims make up 300 thousand of the five hundred thousand population who do not have any tendency to engage with such an activity. Therefore, the amount people who go to theatre are far few than Europe. On the other hand, the Greeks and Armenians make up the working class of the city and face poverty. They don't have an interest or demand for music, either. People who are most likely to go to theatre are only around 20 thousand. "(Lindau, 1898, in Pinar, 1994)

Figure 16. Kramer Theatere and the Big Theatre (Card postal,in Beyru ,2011)
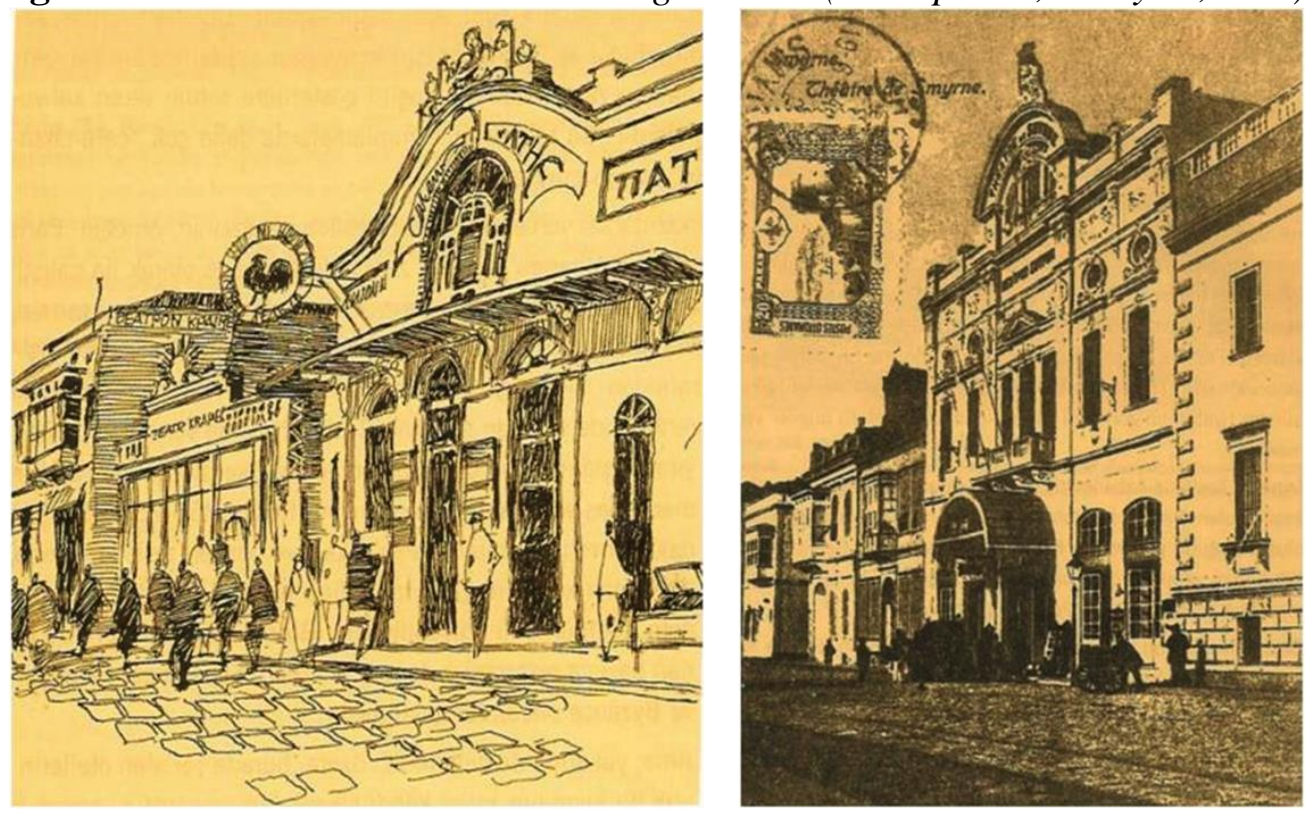

Casinos and clubs were the other favourite cultural spaces that were mentioned in the narrations. At first, the casinos and clubs were serving only for the Western groups and wealthy Levantines. After then, the Greeks and Armenians started to visit these places. At the end of the century these places were also visited by the wealthy Jews and even the Muslims.

For some travellers, these casinos and clubs were compatible to the ones in Europe, while for others they were below the standard.

"Some of the club which constitute a central place in social life of $19^{\text {th }}$ century Izmir are situated on the first Kordon. Among them, there are The Greek Casino, Hunters and Sporting Clubs. Towards the end of the $19^{\text {th }}$ century, the Sporting club started to host theatre, concerts or shows." (in Beyru,2001)

"Merchants of all nations own a meeting places called "Casin", which at the same time can be considered as both Wauxhall of Izmir and stock market. In these place, people would dance and transact their businesses. During the Carnaval time, members would raise money and share the cost of the expenses to organise balls 
Vol. 1, No. 1 Taşci et al.: Rediscovering the $19^{\text {th }}$ Century of a Port Town in Levant...

gathering the most distinguished communities of Frank road for the women " (Tancoigne, 1817, in Yaranga, 2002)

“(...) I had a chance to see a casino(...) I was introduced to many Europeans there. Although many had their own cultural traditions, none of them could ever compete with the level of knowledge of a merchant in England." (Fellows, 1838, in Pinar, 1994

Figure 17. Sporting Club (Card postal, in Beyru,2011)

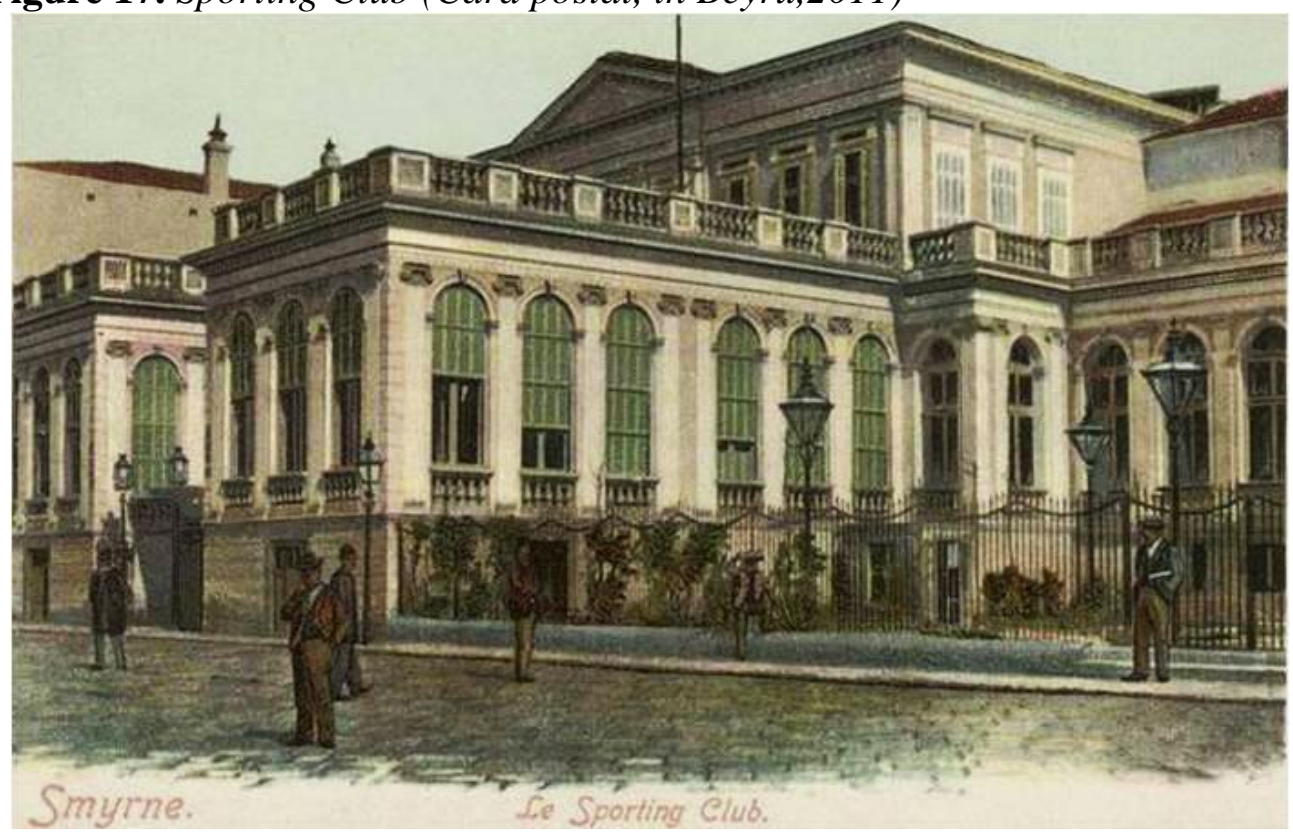

Besides the other cultural places, Coffee Houses were playing an important role in social life. However, the dual character of the city was also affected the forms, usages and the locations of the coffee houses of different communities. For Muslims, coffee houses were placing in the centre of the social life of the men. Men were chatting, playing backgammon, smoking water-pipe, reading newspapers and books in these coffee houses. These coffee houses were usually located around the Kervan Bridge while they can also be seen all over the Muslim neighbourhood.

"Coffeehouses are always decorated with ivy, which offers a very nice appearance. Except from the tough winters, the Turks would drink their coffees in outdoor under pergolas. I think they spend more time outdoor than inside. (Lane, 1837, in Beyru, 2011)

"...Coming back to Turkish coffee houses, petition-writer would sit in front of the door and wait for a customer to write formal petition in Turkish, Persian and Arabic. What is being offered in Turkish coffeehouses are quite limited, people can drink Turkish coffee and smoke water-pipe. Turkish coffee houses pay more attention to hygiene than the Christian cafes. When it comes to prices, the 
Christian cafes are four times more expensive than Turkish coffee houses. Therefore, honesty is an important characteristic of the Turks. (Barth, 1892, in Pınar, 1996)

Figure 18. Coffee Houses of Muslim community (Raffet, 1837, in Maeso \& Lesvinge, 2013)

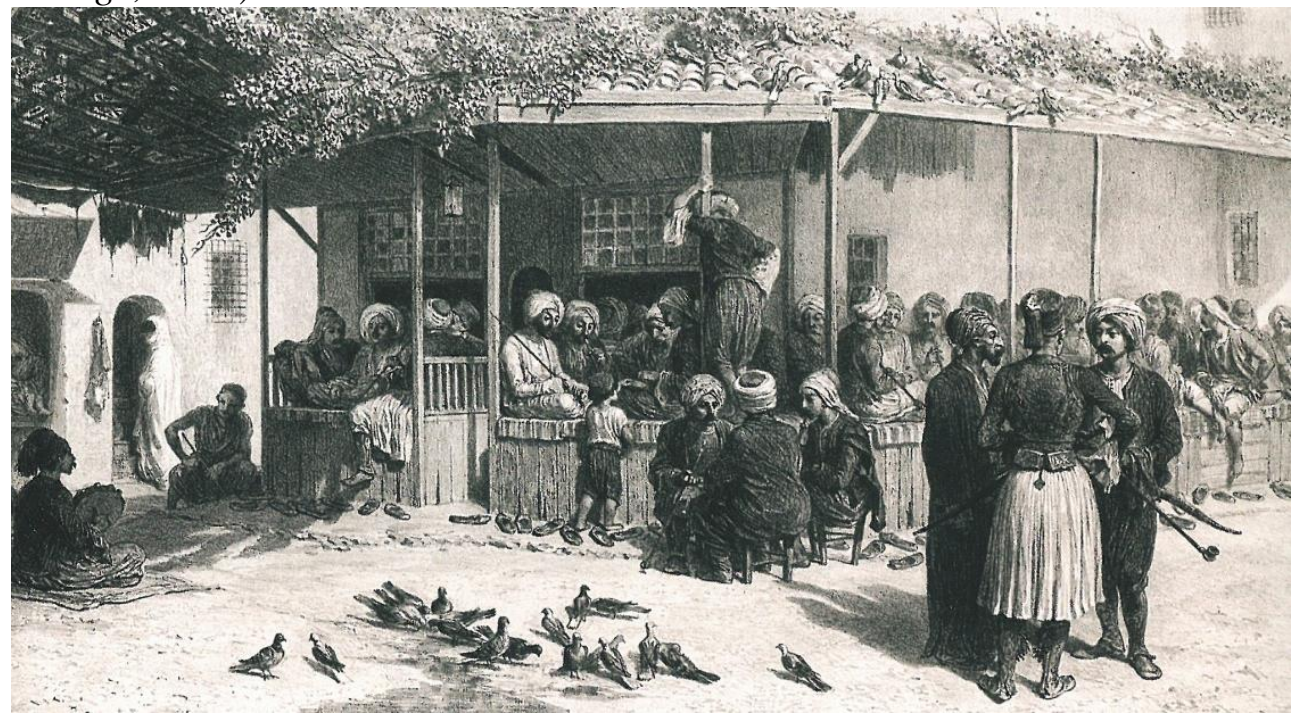

Due to the cultural and social interaction, the Levantine community also formed their coffee houses in in their own architectural forms and in their neighbourhoods. These samples were usually seen on and around the coastline of the city, especially on the southern part of Kordon that was known as Bellavista.

"The Levants would prefer Bellavista coffeehouses for their evening walks. This coffeehouse is situated on a pier, where they would watch the ships in the harbour, eat ice cream, read some European newspapers and would watch Greek girls walking around" (Du Camp, 1849, in Yaranga,2002) 
Figure 19. Coffeehouses on Bellavista (Cardpostal, in Beyru, 2011)

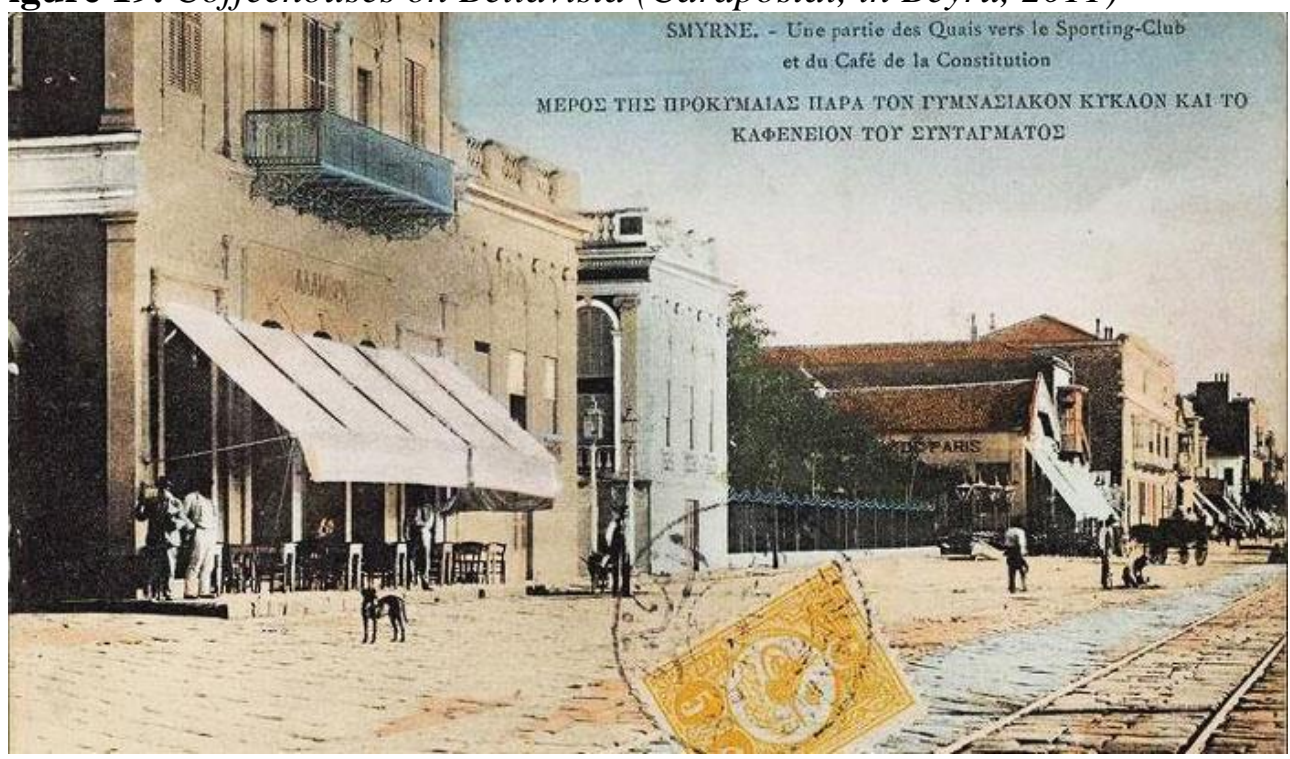

Figure 20. Turkish Coffeehouse (in 19th century, levantineheritage.com)

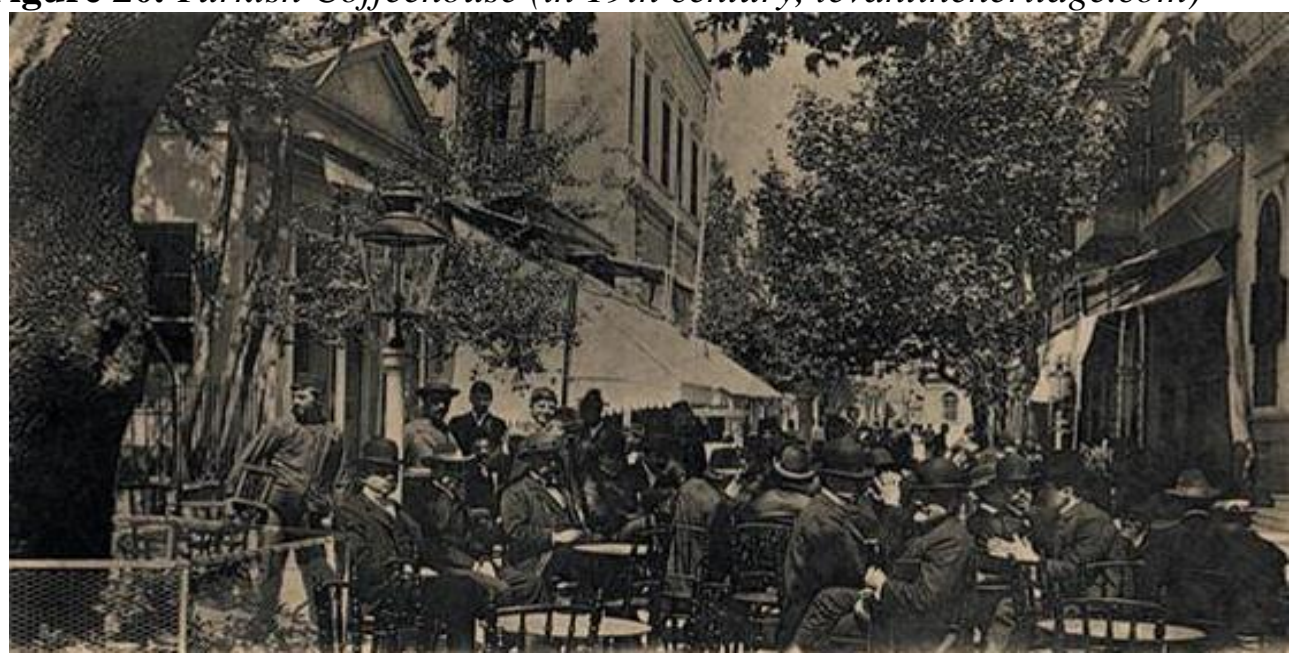

\section{Conclusion}

When all the descriptions, told by different travellers and focused on different parts of the city are analyzed, different perceptions related to the city are determined. Among these differences, the most significant issue is about the character of the city. According to some narrations, Smyrna appears as an eastern city while it strikes as a western town for the others. According to these descriptions, the urban structures of the Muslim Turks and Jews formed the Eastern character of the city, while the social and physical structure of the Levantines, Greeks and the Armenians were representing the Western part.

Based on the descriptions, it is observed that the fragmented urban character that is shaped by the multi-cultural society is the main effect of this dual character. The cosmopolite society; the ethnic variety; the housing 
districts that were shaped by proper ethnic or religious groups; the differences between the social and cultural activities of different groups are the main inputs of the fragmented urban character. On the other hand, the socio-cultural experiences in different parts of the city were also affected the different perceptions of the city.

Besides the dual character of the city, the variable descriptions related to the same part of the city are remarkable. These variations can be explained by the prejudice of the visitors, besides their professions, nationalities, cultural backgrounds, and also the purpose and duration of their visit may affect their perceptions and descriptions.

\section{References}

Beyru, R. 2011. The City of Izmir in 19th Century. Istanbul: Literatür Publishing.

Güzel, E. 2010. The Reflection of Travelogue and Engravings on Urban Architecture of Aegean (18th and 19th centuries), PhD Thesis, Van: Yüzüncü Yıl University.

Pinar, İ. 1994. Travellers' Viewpoint About Izmir XIX.Century I, Izmir: Akademi Bookstore

Pinar, İ. 1996. Travellers' Viewpoint About Izmir XIX.Century II, Izmir: Akademi Bookstore

Yaranga, O. 2002, In the First Half of the 19th Century French Travellers' Exppression of Izmir, Izmir Metropolitan Municipality Culture Publishing.

Maeso, J.L., Lesvinge, M.V. 2013, Smyrna in 18th and 19th Centuries:A western Perspective, Izmir: Mas Printery 
